\title{
Science Education in Egypt and Other Arab Countries in Africa and West Asia
}

\section{Farkhonda Hassan}

\section{Introduction}

S I N CE THE PRES I DEN T I A L Declaration Education is a national priority" three years ago, massive reform of Egypt's education has taken place. The move toward a private economy has added urgency to this reform.

The Egyptian education system is large, and current practices are very rigid. It is accustomed to mass education as was developed in Europe over the past two hundred years, following closely the British tradition. Full-scale renovation of the existing system will take time; a ten-year period is estimated.

As in many other developing countries, the progress of education is affected by a number of overwhelming problems, including rapid population growth, unsustainable development, unemployment, debts, and structural adjustment. However, unlike other developing countries undergoing similar structural adjustment, Egypt's budget for education for the year 1995/1996 has grown to four times as much as that of 1990/1991.

Science and Technology at the Pre-University Level

Significant changes are taking place in science programs offered to future citizens. Traditional patterns of science education, which build a strong theoretical tradition with less emphasis on laboratory and practical experiences, are changing rapidly. New programs and systems with more emphasis on research are being introduced. The content and teaching methods incorporated in these programs are based on the most up-to-date theories about what science is most worth knowing. The primary goal of the new generation science programs is to reflect the national interest of having a scientifically literate population. 
Science education starts at a very early stage, and it is a compulsory subject up to the age of sixteen. Science education starts at the kindergarten level with simple activities and continues in this way until the third year (ages 4-9). In this early period there is no science as such, but the scientific aspects of several activities are emphasized indirectly. After this interval, the education system favors integrated science courses up to the end of the first year of secondary school (age 9-16). In the last two years (age 16-18), science is separated into its major branches and known disciplines. The amount of instruction time devoted to science is generally substantial and no doubt reflects the opinion that learning science provides excellent opportunities for the development and practice of basic skills. Students devote substantially different fractions of their time to the study of science, as much as almost half at the terminal secondary school stage. However, the fraction of time spent in practical work is not satisfactory.

At present science education is facing a rapidly expanding school system, a critical shortage of trained teachers, as well as a lack of materials and facilities. Teachers' empowerment by means of improving their science teaching skills is another goal of our educational reform. Policy initiatives to address the quality of the teaching force include the establishment of teacher training programs, providing both preservice and in-service training opportunities.

In our drive for economic growth and technical development we have turned to outside assistance, which is being given by friendly countries (e.g., United States, Germany \{Mubarak-Cole Program\}, Holland and international organizations), in terms of materials, manpower, and training programs.

\section{Higher Education in Egypt and Arab Countries}

Higher education in Egypt is organized in three institutional models:

1. The universities: a higher educational institution organized into colleges (faculties).

2. The four-to-six-year colleges or institutes: each institute offers programs in one of the major fields, such as engineering, computer science, agriculture, and so on. Some of these institutions were 
reorganized to become part of a university (University of Helwan); others still exist as such.

3. The two-to-three-year institutes: they offer programs that lead to a diploma. The same pattern is followed more or less in other Arab countries in Northern Africa and West Asia.

The Arab higher education system has been drastically expanding during the past two decades. The number of universities has grown to 132, with many more planned, and may exceed 150 by the year 2000 . Over one-third of Arab universities are less than fifteen years old, while almost one-half of the colleges within the universities as a whole were established during the last seven years (Fig. 1 and Table 1).

The Science and Technology Structural Component in the Higher Education System

The share of science and technology colleges in the three models of higher education amounted to 51 percent compared with 49 percent for humanities and social sciences in 1993. The trend in the overall composition of science and technology colleges showed an increase in the share of engineering, technology, and medical colleges compared with the share of basic and agricultural sciences (Fig. 2). Algeria leads all Arab states in the number of science and technology colleges, followed by Egypt.

The increase in engineering and technology was more marked in the newer disciplines such as electronics, computer, and informatics.

One-third of the science and technology colleges granted the Ph.D. degree, compared with one-half that granted the M.S. degree (1993).

Student Enrollment at the B.S. Level

Higher education student enrollment in the Arab states has almost doubled during the period from 1980 to 1992 . The annual rate of increase in student enrollment varied drastically among Arab states and averaged from a high of 50 percent in Mauritania in Africa to a low of 0.5 percent in Egypt (Fig. 3). These growth rates usually reflect the maturity stage of higher education as well as the admission policy in each of the Arab states. The drop in the average rate of increase in the 
case of Egypt, from 7 percent during the period 1980- I 981 to 0.5 percent during the period 1985-1992, was due to the rationalized admission policy of B.S. students enforced since 1985 .

\section{TABLE 1.}

Distribution of Number of Universities by Each of the Arab States

\begin{tabular}{lcl}
\hline $\begin{array}{l}\text { Number of } \\
\text { Universities }\end{array}$ & $\begin{array}{c}\text { Total } \\
\text { Number }\end{array}$ & State \\
\hline 1 & 7 & $\begin{array}{l}\text { Djibouti, Kuwait, Mauritania, } \\
\text { Oman, Qatar, Somalia, U.A.E. }\end{array}$ \\
\hline 2 & 2 & Bahrain \\
\hline 3 & 3 & Yemen \\
\hline 4 & 4 & Syria \\
\hline 8 & 6 & Tunisia \\
\hline 9 & 16 & Palestine (West Bank and Gaza) \\
\hline 11 & 18 & Jordan, Lebanon \\
\hline 13 & 22 & Iraq, Libya \\
\hline 15 & 39 & Algeria, Eqypt, Morocco \\
\hline TOTAL & 15 & Sudan \\
\hline
\end{tabular}

FIGURE 1.

Growth in Number of Universities in the Arab States During 1950-1993

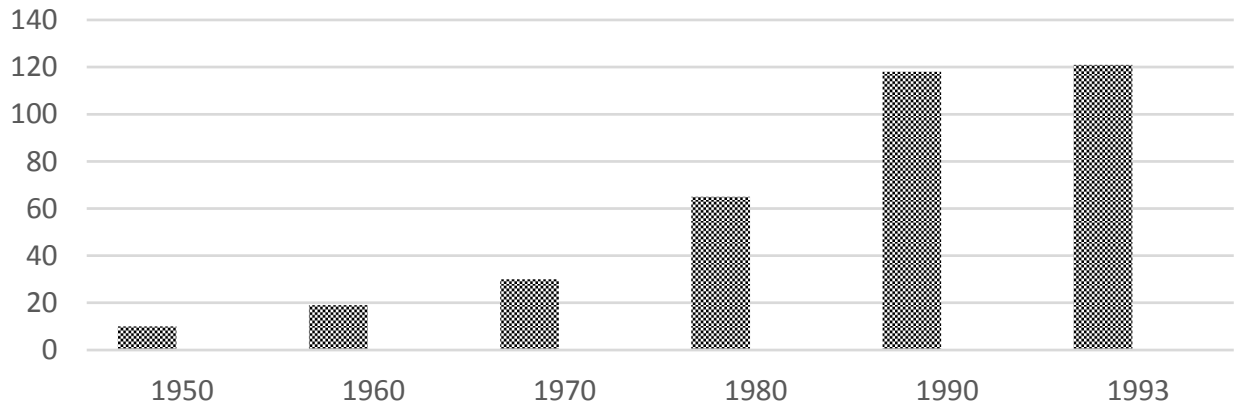




\section{FIGURE 2.}

\section{Growth in Number of University Colleges in the} Arab States in 1984 and 1993

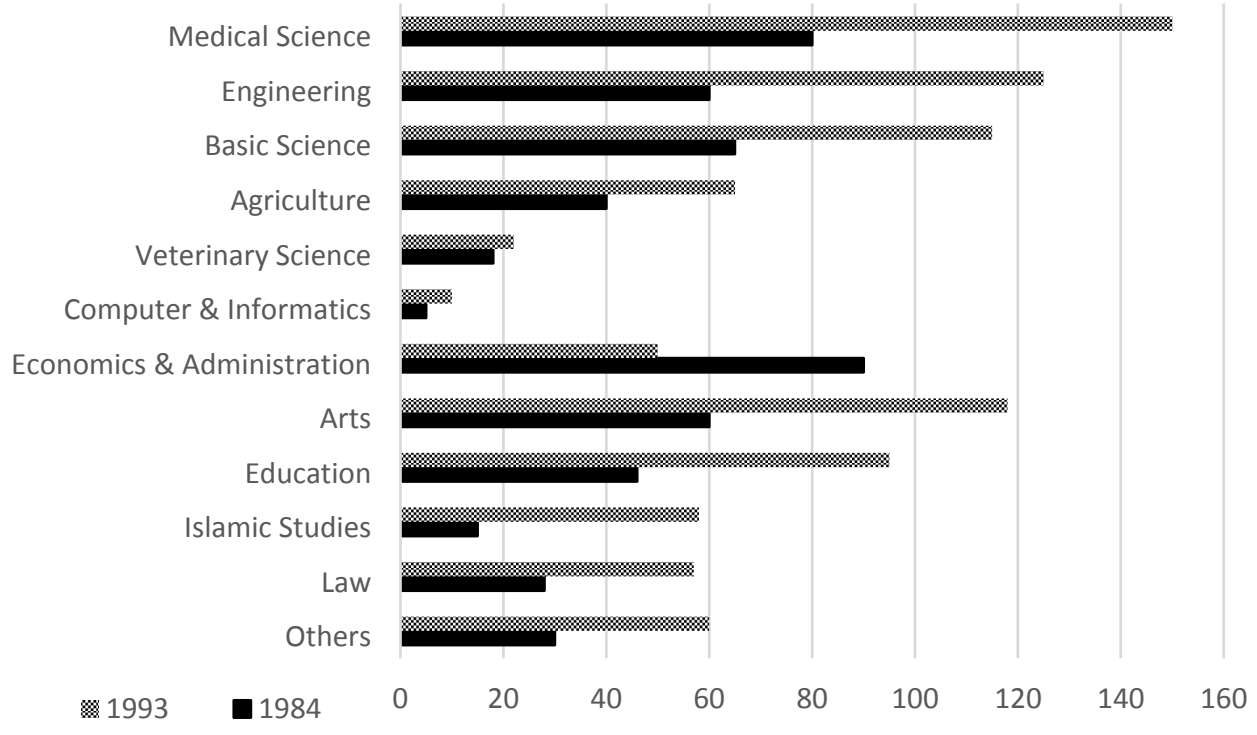

About 9 percent of the total number of students in higher education in the Arab states were enrolled outside their home state in 1990/1991. The ratio of those studying abroad at the B.S. level varied from a high of 45 percent for Jordan to a low of only a fraction of I percent in Egypt. Forty-seven percent of students enrolled abroad were in other Arab countries. Foreign countries most sought by Arab students in descending order are France, United States, Russia, Germany, United Kingdom, India, Turkey, and Pakistan. The most diverse group of Arab students with regard to their country of origin are those studying in the United States.

The ratio of students enrolled in science and technology at the B.S. level was 41 percent in 1980 and decreased to 35 percent in 1990-1991. The distribution of student enrollment by science and technology fields varied widely for each discipline. (Table 2.) At the technical institute diploma level, the share of students enrolled in engineering and 
technology was highest among the four $\mathrm{S}$ and $\mathrm{T}$ fields and amounted to 29 percent as compared with 3 percent in agriculture.

The number of B.S. graduates per 100,000 population and their distribution by Science and Technology disciplines is given in Table 3 .

\section{Distribution of B.S. Students by Sex}

The share of females enrolled in science and technology fields is an indicator of human development in society; the higher the share, the better the level of human development. The number of female students enrolled at the B.S. Ievel in all Arab states is equivalent to 35 percent of the total for 1990/1991 as compared with 33 percent for 1984/1985. The ratio of females to total enrollment in each state varied widely and averaged a high of 71 percent in United Arab Emirates, middle range of 35 percent in Egypt to a low of 8 percent in Djibouti (Table 4). Female students in the Arab States dominated the fields of arts and humanities. Their share in these fields has averaged 54 percent followed by 15 percent in economics and administration. The share of female students enrolled in science and technology fields has totaled only 31 percent. The distribution of the female ratio by discipline within each state has also varied considerably (Table 5). The variation by discipline was highest in the basic sciences, which amounted to 12 percent followed by 9 percent for medical sciences and 8 percent in engineering. Female students in most Arab states had a high demand for science and technology disciplines like pharmacy and dentistry. In the basic sciences the demand was for life sciences and chemistry rather than for physics and mathematics. Computer science is becoming a popular choice for female students.

\section{Science and Technology Graduates}

An important indicator in human capital formation is the ratio of graduates at the Ph.D. and M.S. levels of all higher education graduates. The higher the ratio of this group, the more developed, usually, is the higher education system in a state. Egypt's share of graduates at both the M.S. and Ph.D. level amounted to 50 percent of total Arab graduates for the period of 1980-1993. 
The ratio of science and technology graduates to the total number of Arab graduates averaged 35 percent in all Arab states for the same period, but varies from 60 percent in Algeria to 14 percent in Djibouti.

\section{FIGURE 3.}

\section{Percentage Annual Average Growth of Enrollment of}

\section{B.S. Students in Arab States During 1980-1991}

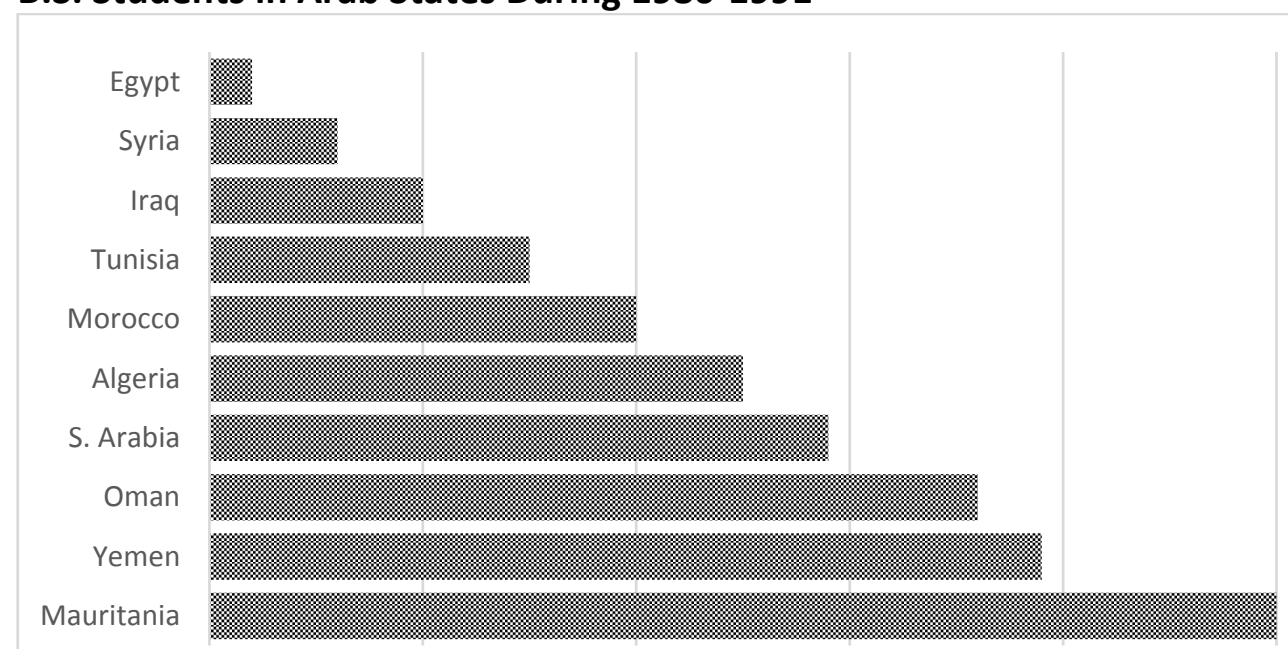

TABLE 2.

Percentage Distribution of Arab B.S. Student Enrollment by Field of Study in 1980, 1985, 1991

\begin{tabular}{lccc}
\hline Field of Study & \% Distribution of the Total Students & Enrolled \\
\hline & $\mathbf{1 9 8 0}$ & $\mathbf{1 9 8 5}$ & $\mathbf{1 9 9 1}$ \\
\hline Basic Science & 9 & 9 & 12 \\
\hline Engineering & 14 & 12 & 11 \\
\hline Medical Science & 10 & 9 & 8 \\
\hline Agricultural Science & 7 & 6 & 4 \\
\hline Subtotal S \& T & $\mathbf{4 1}$ & $\mathbf{3 6}$ & $\mathbf{3 5}$ \\
\hline Econ. and Admin. & 18 & 17 & 15 \\
\hline Arts and Hum. & 41 & 47 & 50 \\
\hline Subtotal Hum. & 59 & 64 & 65 \\
\hline TOTAL & $\mathbf{1 0 0}$ & $\mathbf{1 0 0}$ & $\mathbf{1 0 0}$ \\
\hline Total B.S. Students & $\mathbf{1 , 0 2 9}$ & $\mathbf{1 , 4 8 4}$ & $\mathbf{1 , 7 9 2}$ \\
\hline
\end{tabular}




\section{M.S. Student Enrollment and Graduates}

The total student body enrolled at the M.S. level in all disciplines for all Arab states amounted to $4.3 \%$ of the total student enrollment in higher education. The ratio of M.S. students enrolled in science and technology fields amounted to $46 \%$ in 1990/91. The highest ratio of M.S. students in the science and technology fields was in medical fields which amounted to $14 \%$ (1990/91), followed by basic sciences and engineering with $12 \%$ of the total for each. The annual growth between 1985 and 1991 in students enrolled at the M.S. level was 12\%. The ratio of one M.S. graduate to every 22 B.S. graduate is an average for all Arab states.

\section{Ph.D. Student Enrollment and Graduates}

The Ph.D. is the basic professional degree in most fields of science. The ratio of Ph.D. enrollment to total higher education student enrollment was only 1.3 percent in 1990/1991. The share of the leading six Arab states in total number of Ph.D. candidates adds up to 84 percent. The share of Egypt alone was 64 percent, followed by Morocco (14 percent), Algeria (9 percent), Saudi Arabia (7 percent), Tunisia (4 percent) and Jordan (4 percent). Almost 50 percent of Ph.D. candidates study outside their home state. Arab states vary widely in their institutional capacity to grant the Ph.D. degree. Egypt is the only state with institutions that offer Ph.D. programs in all major fields of study.

Sixty-six percent of Ph.D. candidates were enrolled in science and technology fields in 1990/1991. Basic sciences and medical sciences each had a share of 17 percent of the total enrollment, followed by engineering and agriculture with 14 percent for each. It is interesting to note that the share of Egypt alone of Ph.D.'s enrolled in all Arab states was 30 percent in basic sciences, 40 percent in engineering, 50 percent in medical sciences, and 78 percent in agriculture (1993).

The quality of most Ph.D. granting science programs in Egypt and their graduates is very high. Graduate education in sciences is a long and expensive process. The government is the only funding source for Ph.D. and M.S. production in Egypt. Most graduate fields in the 
sciences, as distinguished from engineering, are oriented towards the academic job market.

Sixty-eight percent of Ph.D. graduates are in science and technology fields. Of all Ph.D. graduates, 19 percent were in the basic sciences. The share of Egypt of total Ph.D. graduates in science and technology amounted to 52 percent; on the other hand, Egypt's share of total graduates in medical sciences was 67 percent, in agriculture 78 percent, in engineering 41 percent and in the basic sciences 31 percent, which is very close to its share of the overall Ph.D. enrollment. Most of the Ph.D. scientists seek research or teaching positions and work in academic institutions. However, the attractiveness of an academic career is fading currently, due to low wages as compared with the new job opportunities being generated by increasing privatization and the evolving free market economy.

\section{High Education Staff Members}

By 1990/1991, three positive developments had taken place since 1985 with regard to the overall staff member composition in the Arab states: first, the increase of staff members in rates higher than those in student enrollment; second, the decrease of expatriate staff members working in the Arab states (11 percent in 1990/1991 as compared with 16 percent in 1984/1985); and third, the improvement in the overall ratio of Ph.D. degree holders of total staff members (63 percent in 199()/1991 compared with 52 percent in 1984/1985).

The ratio of staff members in science and technology fields amounted to 62 percent if the number of full professors among staff members is used as an indicator of maturity in the staff member comparison. The ratio of this professorial rank amounted to 20 percent of Ph.D. holders. It is of interest to note Egypt's high share of total staff in the professional rank, which amounted to 45 percent (1990/1991) compared with its share of only 15 percent of the total staff, a situation that reflects the maturity of Egyptian universities. The ratio of professorial rank of total staff members within each state has ranged from a low of 2 percent in Somalia to a high of 23 percent in United Arab Emirates. Most Arab Gulf states have a high ratio of staff members at the professorial rank, which reflects the high ratio of non-national 
professors working in their institutions. The distribution of nonnational staff members varies widely among Arab states and ranged from less than 1 percent in Egypt to 96 percent in United Arab Emirates.

\section{TABLE 3.}

\section{Ranking of Arab States in Descending Order in}

\section{Number of B.S. Graduates per 100,000 Population and}

Their Distribution by S\&T Discipline in 1990/1991

\begin{tabular}{|c|c|c|c|c|c|c|c|}
\hline State & $\begin{array}{l}\text { B.S. graduates } \\
\text { per } 100,00 \\
\text { population }\end{array}$ & $\begin{array}{c}\text { Basic } \\
\text { Science }\end{array}$ & Engin. & $\begin{array}{l}\text { Medical } \\
\text { Science }\end{array}$ & $\begin{array}{l}\text { Agric. } \\
\text { Science }\end{array}$ & $\begin{array}{c}\text { Total } \\
\text { S\&T }\end{array}$ & $\begin{array}{l}\text { Total } \\
\text { H\&SS }\end{array}$ \\
\hline Lebanon & 339 & $15 \cdot 4$ & 5.9 & 5.6 & 1.9 & 28.8 & 71.2 \\
\hline Jordan & 264 & 13.7 & 16.3 & 10.1 & 3.9 & 44 & 56 \\
\hline Libya & 207 & 13.7 & 8.7 & 5.8 & 6.6 & 34.8 & 65.2 \\
\hline Qatar & 202 & 4.7 & 2.1 & 2.2 & 0.2 & 9.2 & 90.8 \\
\hline Egypt & 200 & 4 & 6.6 & 6.1 & 5.7 & 22.4 & 77.6 \\
\hline Bahrain & 191 & 9.2 & 28.6 & 3.6 & 0.3 & 41.7 & 58.3 \\
\hline Kuwait & 190 & $17 \cdot 3$ & 10.6 & 2.1 & - & 30 & 70 \\
\hline Iraq & 141 & 10.1 & 7.2 & 6.1 & 5.1 & 28.5 & 71.5 \\
\hline Palestine & 134 & 15.4 & 14.2 & 7.9 & 3 & 40.5 & 59.5 \\
\hline Syria & 115 & 10 & 24.4 & 15.2 & 4.1 & 53.8 & 46.2 \\
\hline Tunisia & 109 & 50.9 & 5.7 & 8 & 2.9 & 67.5 & 32.5 \\
\hline Algeria & 104 & 14.7 & 24.8 & 11.6 & 5.4 & 56.5 & 43.5 \\
\hline Morocco & 91 & 23.6 & 4.1 & $5 \cdot 5$ & 1 & 34.2 & 65.8 \\
\hline Djibouti & 86 & 8.2 & 4.5 & 0.9 & - & 13.6 & 86.4 \\
\hline S. Arabia & 84 & 10.1 & 4.4 & 6.3 & 2.9 & 23.7 & 76.3 \\
\hline Mauritania & 81 & 12.9 & 15.8 & 4.2 & - & 32.9 & 67.1 \\
\hline UAE & 77 & 11 & 9 & 0.8 & 21 & 22.9 & 77.1 \\
\hline Oman & 50 & 13.7 & 11.5 & 5.7 & 11.5 & 42.4 & 57.6 \\
\hline Sudan & 29 & 11.6 & 10.8 & 15.8 & 11 & 49.2 & 50.8 \\
\hline Yemen & 26 & 5.6 & 11.1 & 10.1 & 7.6 & 34.4 & 65.6 \\
\hline Somalia & 24 & 11.6 & 9.6 & 3.7 & 11.8 & 36.7 & $63 \cdot 3$ \\
\hline AVERAGE & 121 & 11.3 & 9.9 & $7 \cdot 4$ & 4.8 & $33 \cdot 3$ & 66.7 \\
\hline
\end{tabular}




\section{TABLE 4.}

Percentage Ratio of B.S. Female Students of

Total Enrollment in 1990/1991

\begin{tabular}{llc}
\hline $\begin{array}{l}\text { \% Females of } \\
\text { Total Student } \\
\text { Enrollment }\end{array}$ & State & $\begin{array}{c}\text { \% Share of } \\
\text { Group States } \\
\text { of Total }\end{array}$ \\
\hline $67-70$ & UAE, Qatar, Bahrain, Kuwait & 1.7 \\
\hline $45-50$ & Oman, Lebanon, Sudan & 8.1 \\
\hline $35-40$ & Iraq, Palestine, Tunisia, Morocco, Syria, Egypt & 63.8 \\
\hline 35 & All Arab states average & - \\
\hline $27-31$ & Libya, Saudi Arabia & 10.4 \\
\hline $14-17$ & Yemen, Somalia, Mauritania & 3 \\
\hline 8 & Djibouti & less than 0.1 \\
\hline
\end{tabular}

The Staff to Student Ratio

The ratio of staff to students is one of the more common and reliable indicators in measuring the quality of teaching in a university or university-level institution There is no golden rule Mr. what constitutes an ideal SATs to student ratio Several variables play a role in the determination of this ratio level The majority of Arab states do not enjoy a good stranding with regard to the SATs to student ratio In Egypt the SATs to student ratio in science and technology fields, calculated on the basis of the Ph.D. only, ranges from a low of 1:7 to a high of 1:18. This situation is not unique to Egypt but is common for many other Arab states. 


\section{TABLE 5.}

Percentage Distribution of Total Females Enrolled at the B.S. Level in National Institutions by Discipline for the Academic Year 1990/1991

\%Distribution of Female Students at the B.S. Level

\begin{tabular}{lcccccc} 
State & $\begin{array}{c}\text { Basic } \\
\text { Science }\end{array}$ & Engin. & $\begin{array}{c}\text { Medical } \\
\text { Science }\end{array}$ & $\begin{array}{c}\text { Agric. } \\
\text { Science }\end{array}$ & $\begin{array}{c}\text { Econ. and } \\
\text { Admin. }\end{array}$ & $\begin{array}{c}\text { Arts and } \\
\text { Hum. }\end{array}$ \\
\hline Algeria & 18.8 & 27.3 & 15.1 & 2.1 & 7.8 & 28.9 \\
\hline Bahrain & 15.6 & 6 & 11.8 & - & 15.3 & 51.3 \\
\hline Djibouti & - & - & - & - & 28 & 72 \\
\hline Egypt & 3.1 & 2.9 & 9.8 & 5.2 & 21.1 & 57.9 \\
\hline Iraq & 11 & 14.9 & 7.1 & 2.4 & 14.4 & 50.2 \\
\hline Jordan & 15.9 & 7.2 & 11.1 & 4 & 14.1 & 47.7 \\
\hline Kuwait & 17.2 & 8.4 & 4.7 & - & 16.4 & 53.2 \\
\hline Lebanon & 18.9 & 6 & 14.5 & 3.5 & 15 & 42.1 \\
\hline Libya & 15.8 & 5 & 7.2 & 4.6 & 17.4 & 50 \\
\hline Mauritania & 10 & 3.8 & - & - & 12.5 & 73.7 \\
\hline Morocco & 26.3 & 0.6 & 3.8 & 0.5 & 11.6 & 57.2 \\
\hline Oman & 13.5 & 2.5 & 9.5 & 1.1 & - & 73.4 \\
\hline Palestine & 15.8 & 2.7 & 3 & 0.1 & 11.4 & 67 \\
\hline Qatar & 13.8 & - & - & - & 4.7 & 81.5 \\
\hline Saudi Arabia & 17 & 0.1 & 7.3 & 2.4 & 8.4 & 64.8 \\
\hline Somalia & - & - & - & - & - & 100 \\
\hline Sudan & 5.1 & 3 & 4.3 & 3 & 29.8 & 54.8 \\
\hline Syria & 10.7 & 10.7 & 8.5 & 2 & 7.4 & 60.7 \\
\hline Tunisia & 12.4 & 4.6 & 11.1 & 1.4 & 14.6 & 55.9 \\
\hline UAE & 10.4 & 6.2 & 6.1 & 1.8 & 13.9 & 61.6 \\
\hline Yemen & 7.8 & 2.8 & 11.7 & 0.7 & 10.2 & 66.8 \\
\hline TOTAL & 12.8 & 7.6 & 9.4 & 3 & 14.8 & 52.4 \\
\hline & & & & & &
\end{tabular}

The Scientific Community in Egypt

Healthy growth of science and technology in any country depends on the availability of technically and scientifically trained manpower, and it is the responsibility of the indigenous educational system to produce the adequate stock. Over the past four decades, Egypt has created an impressive number of trained people. However, as in many developing countries, the scientific community as a whole is still an underutilized resource, and its participation in developmental activities is not yet effective; its impact on the production sector in the country is 
rather weak. Unfortunately, current educational systems in most Third World countries have not sufficiently addressed themselves to development problems. We still import foreign technology to a large extent and utilize foreign experience. Technological and scientific dependence of the Third World is a state of mental subordination that arises from a sense of inferiority towards science and technology. The feeling of inferiority regarding indigenous science and technology, which is particularly serious among decision makers in general, tends to inhibit scientific and technological initiatives in the south. In addition, the low percentage growth in research funds has left many young Ph.D.'s underutilized. Many have left the country, some make up most of the faculty of Arab universities, and some contribute to the further development of developed countries.

The lack of appreciation of science and consequently the lack of incentives for scientist's result in a lack of general interest among high school graduates to take up science as a profession. All these barriers must be overcome.

NOTES

All data and tables concerning Arab countries are taken from the report "The Higher Education System in the Arab States," prepared by Subhi Qasem for UNESCO, published in Cairo, 1995.

Information concerning education in Egypt is taken from official national reports. 